Supporting Information

\title{
Solvent-Dependent Changes in the Ene Reaction of RTAD with Alkenes: The Cyclopropyl Group as a Mechanistic Probe
}

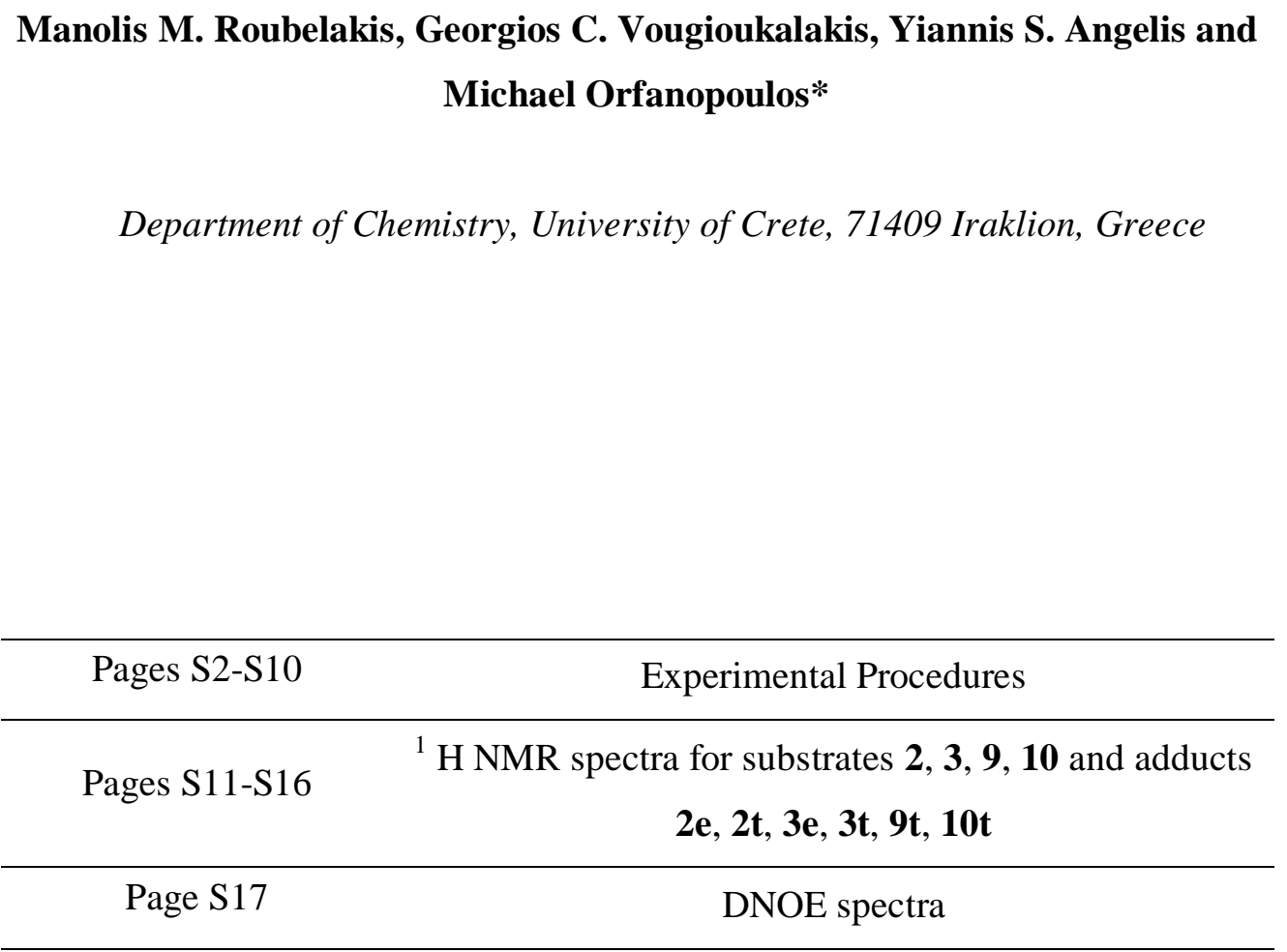




\section{A) Experimental Procedures}

General Considerations. ${ }^{1} \mathrm{H}$ and ${ }^{13} \mathrm{C}$ NMR spectra were recorded on a $500 \mathrm{MHz}$ (125 $\mathrm{MHz}$ for ${ }^{13} \mathrm{C}$ ) spectrometer, in $\mathrm{CDCl}_{3}$ or $\mathrm{CD}_{3} \mathrm{OD}$ solutions. Chemical shifts are reported in ppm downfield from $\mathrm{Me}_{4} \mathrm{Si}$, by using the residual solvent peak as internal standard. Isomeric purities were determined by ${ }^{1} \mathrm{H}$ NMR. TLC was carried out on $\mathrm{SiO}_{2}$ (silica gel $\mathrm{F}_{254}$ ). Chromatography refers to flash chromatography and was carried out on $\mathrm{SiO}_{2}$ (silica gel 60, SDS, 230-400 mesh ASTM). Drying of organic extracts during workup of reactions was performed over anhydrous $\mathrm{MgSO}_{4}$. Evaporation of the solvents was accomplished with a rotary evaporator.

General procedure for the triazolinedione-alkene ene and trapping reactions. Equimolar amounts of the alkene and PTAD were dissolved in the appropriate deuterated solvent $(0.7 \mathrm{ml})$, in a NMR tube. The reaction mixture was shacked well and after a few minutes a yellow-pink color predominated. Next, the ${ }^{1} \mathrm{H}$ NMR spectrum of the mixture was recorded. If necessary, the reaction mixture was subjected to flash chromatography, with a mixture of hexane/ethyl acetate $1 / 3$ as an eluent. When the reaction was carried out in $\mathrm{CD}_{3} \mathrm{OD}$, a small percentage of the ene products was also formed, apart from the trapping products. The separation of these two products by column chromatography was proved to be impossible.

Synthesis of compounds 2 and 3. Compounds 2 and 3 were prepared from the commercially available trans-2-phenylcyclopropanecarboxylic acid (13) according to the following procedure: 


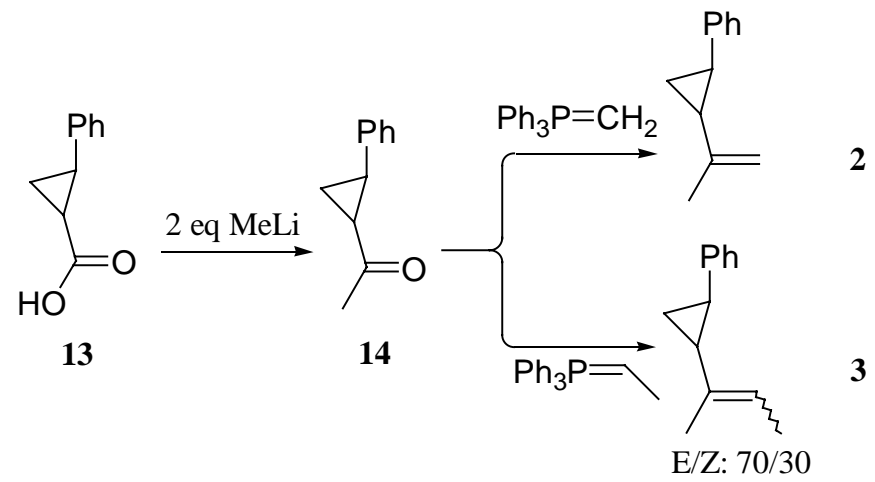

(trans-2-phenylcyclopropyl)ethanone (14). MeLi (43.3 mL, 1.5 M in ether, 65.0 mmol) was slowly added, under a nitrogen atmosphere, to a cooled solution $\left(-78{ }^{\circ} \mathrm{C}\right)$ of the carboxylic acid $\mathbf{1 3}(5 \mathrm{~g}, 31.0 \mathrm{mmol})$ in anhydrous ether. The reaction mixture was stirred at $-78{ }^{\circ} \mathrm{C}$ for $15 \mathrm{~min}$ and then was warmed to $0{ }^{\circ} \mathrm{C}$, stirred for $1 \mathrm{~h}$, and carefully treated with water. The etheral phase was separated, dried $\left(\mathrm{MgSO}_{4}\right)$ and evaporated to provide the ketone $\mathbf{1 4}$ as an oil (4 g, $25.0 \mathrm{mmol}, 81 \%)$. ${ }^{1} \mathrm{H}$ NMR (500 $\left.\mathrm{MHz}, \mathrm{CDCl}_{3}\right): \delta 7.29(\mathrm{dd}, J=7.3 \mathrm{~Hz}, J=7.2 \mathrm{~Hz}, 2 \mathrm{H}), 7.21(\mathrm{t}, J=7.3 \mathrm{~Hz}, 1 \mathrm{H}), 7.09$ (d, J = 7.2 Hz, 2H), $2.52(\mathrm{~m}, 1 \mathrm{H}), 2.30(\mathrm{~s}, 3 \mathrm{H}), 2.22(\mathrm{~m}, 1 \mathrm{H}), 1.67(\mathrm{~m}, 1 \mathrm{H}), 1.38(\mathrm{~m}$, $1 \mathrm{H}) .{ }^{13} \mathrm{C} \mathrm{NMR}\left(125 \mathrm{MHz}, \mathrm{CDCl}_{3}\right): \delta 206.61,140.18,128.36,126.38,125.89,32.72$, $30.66,28.85,18.96$.

1-(2-isopropenylcyclopropyl)benzene (2). A solution of $n$-BuLi $(22 \mathrm{~mL}, 1.4 \mathrm{M}$ in hexanes) was added, under a $\mathrm{N}_{2}$ atmosphere, to a cooled mixture $\left(0{ }^{\circ} \mathrm{C}\right)$ of methyl(triphenyl)phosphonium iodide in dry ether. The solution turned orange due to the formation of the corresponding ylide. After the mixture was stirred for $1 \mathrm{~h}$ at room temperature, a solution of ketone $\mathbf{1 4}(4 \mathrm{~g}, 25.0 \mathrm{mmol})$ in $\operatorname{dry}_{\mathrm{E}} \mathrm{O}(15 \mathrm{~mL})$ was added drop wise. The resulting mixture was stirred at room temperature for $20 \mathrm{~h}$ and then poured into $100 \mathrm{~mL}$ of hexanes. Triphenylphosphine oxide $\left(\mathrm{Ph}_{3} \mathrm{PO}\right)$ precipitated. The solution was filtrated, concentrated, and the residue was chromatographed $\left(\mathrm{SiO}_{2}\right.$, 
hexanes) to give $0.8 \mathrm{~g}$ of the alkene $2(5 \mathrm{mmol}, 20 \%) .{ }^{1} \mathrm{H}$ NMR $\left(500 \mathrm{MHz}, \mathrm{CDCl}_{3}\right): \delta$ $7.25\left(\mathrm{dd}, J_{1}=7.4 \mathrm{~Hz}, J_{2}=7.3 \mathrm{~Hz}, 2 \mathrm{H}\right), 7.14(\mathrm{t}, J=7.3 \mathrm{~Hz}, 1 \mathrm{H}), 7.08(\mathrm{~d}, J=7.4 \mathrm{~Hz}$, 2H), $4.75(\mathrm{~s}, 1 \mathrm{H}), 4.73(\mathrm{~s}, 1 \mathrm{H}), 1.96(\mathrm{~m}, 1 \mathrm{H}), 1.73(\mathrm{~s}, 3 \mathrm{H}), 1.67(\mathrm{~m}, 1 \mathrm{H}), 1.21(\mathrm{~m}$ 1H), $1.08(\mathrm{~m}, 1 \mathrm{H}) .{ }^{13} \mathrm{C}$ NMR $\left(125 \mathrm{MHz}, \mathrm{CDCl}_{3}\right): \delta 145.29,142.88,128.30,125.77$, $125.47,108.59,30.00,24.00,20.66,15.17 . \mathrm{MS}, \mathrm{m} / \mathrm{z}$ (relative abundance): $158\left(\mathrm{M}^{+}\right.$ 26), 143 (100), 128 (78), 115 (43), 91 (26), 80 (30).

The phosphonium salt, which is the precursor to the ylide, was prepared in $90 \%$ yield by mixing iodomethane and an equimolar amount of triphenylphosphine in a round bottomed flask for $12 \mathrm{~h}$ at ambient temperature. The phosphonium salt was collected as a white solid and washed with hot toluene. ${ }^{1} \mathrm{H} \mathrm{NMR}\left(500 \mathrm{MHz}, \mathrm{CDCl}_{3}\right): \delta 7.77(\mathrm{~m}$, $15 \mathrm{H}), 3.27(\mathrm{~d}, J=13.2 \mathrm{~Hz}, 3 \mathrm{H})$.

\section{1-(2-isopropenylcyclopropyl)benzene-PTAD ene adduct (2e).}

${ }^{1} \mathrm{H}$ NMR (500 MHz, $\left.\mathrm{CDCl}_{3}\right): \delta 7.46(\mathrm{~m}, 2 \mathrm{H}), 7.38(\mathrm{~m}, 3 \mathrm{H}), 7.27(\mathrm{~m}, 2 \mathrm{H}), 7.18(\mathrm{t}, J=$ $7.3 \mathrm{~Hz}, 1 \mathrm{H}), 7.09$ (d, J =7.6 Hz, 2H), 5.07 (s, 1H), $5.03(\mathrm{~s}, 1 \mathrm{H}), 4.39$ (d, J = $15.1 \mathrm{~Hz}$ $1 \mathrm{H}), 4.27(\mathrm{~d}, J=15.1 \mathrm{~Hz}, 1 \mathrm{H}), 2.04(\mathrm{~m}, 1 \mathrm{H}), 1.67(\mathrm{~m}, 1 \mathrm{H}), 1.31(\mathrm{~m}, 1 \mathrm{H}), 1.23(\mathrm{~m}$, $1 \mathrm{H})$.

\section{1-(2-isopropenylcyclopropyl)benzene-PTAD trapping adduct (2t).}

${ }^{1} \mathrm{H}$ NMR (500 MHz, $\left.\mathrm{CDCl}_{3}\right): \delta 7.51(\mathrm{~d}, J=7.8 \mathrm{~Hz}, 2 \mathrm{H}), 7.47(\mathrm{t}, J=7.5 \mathrm{~Hz}, 2 \mathrm{H}), 7.35$ $(\mathrm{m}, 6 \mathrm{H}$ of $2 \mathrm{t}$ and $5 \mathrm{H}$ of $2 \mathbf{e}), 5.52\left(\mathrm{dd}, J_{1}=7.0 \mathrm{~Hz}, J_{2}=7.0 \mathrm{~Hz}, 1 \mathrm{H}\right), 4.23\left(\mathrm{dd}, J_{1}=6.8\right.$ $\left.\mathrm{Hz}, J_{2}=6.8 \mathrm{~Hz}, 1 \mathrm{H}\right), 4.08(\mathrm{~s}, 2 \mathrm{H}), 2.58(\mathrm{~m}, 1 \mathrm{H}), 2.47(\mathrm{~m}, 1 \mathrm{H}), 1.57(\mathrm{~s}, 3 \mathrm{H})$.

1-[2-(1-methyl-1-propenyl)cyclopropyl]benzene (3). Alkene 3 was prepared as a mixture of $E$ and $Z$ isomers (70/30 ratio respectively) from ketone $\mathbf{1 4}$ according to the above-mentioned process for alkene 2 . The Wittig reaction was carried out in dry THF. The reagents and quantities used, are the following: ketone 14: $1.5 \mathrm{~g}(9.4$ mmol); ethyl(triphenyl)phosphonium iodide $\left(\mathrm{CH}_{3} \mathrm{CH}_{2}{ }^{+} \mathrm{PPh}_{3} \mathrm{I}^{-}\right): 4.6 \mathrm{~g}$ (11 mmol); 
solution of $n$-BuLi (1.2 M in hexanes): $9 \mathrm{ml}(11 \mathrm{mmol}) .0 .9 \mathrm{~g}$ of compound 3 was collected (yield 57\%), on purification of the crude mixture by column chromatography $\left(\mathrm{SiO}_{2}\right.$, hexane). ${ }^{1} \mathrm{H}$ NMR $\left(500 \mathrm{MHz}, \mathrm{CDCl}_{3}\right): \delta 7.23(\mathrm{~m}, 2 \mathrm{H}$ of $E$ isomer and $2 \mathrm{H}$ of $Z$ isomer), 7.09 (m, 3H of $E$ isomer and $3 \mathrm{H}$ of $Z$ isomer), 5.32 (m, $1 \mathrm{H}$ of $E$ isomer and $1 \mathrm{H}$ of $Z$ isomer), 2.00 (m, $1 \mathrm{H}$ of $Z$ isomer), 1.87 (m, $1 \mathrm{H}$ of $E$ isomer and $1 \mathrm{H}$ of $Z$ isomer), $1.64(\mathrm{~d}, J=6.6 \mathrm{~Hz}, 3 \mathrm{H}$ of $Z$ isomer), $1.62(\mathrm{~m}, 1 \mathrm{H}$ of $E$ isomer), 1.59 (m, $6 \mathrm{H}$ of $E$ isomer), 1.53 (s, $3 \mathrm{H}$ of $Z$ isomer), 1.16 (m, $1 \mathrm{H}$ of $E$ isomer and $1 \mathrm{H}$ of $Z$ isomer), 1.08 (m, $1 \mathrm{H}$ of $Z$ isomer), 0.98 (m, $1 \mathrm{H}$ of $E$ isomer). ${ }^{13} \mathrm{C}$ NMR $\left(125 \mathrm{MHz}, \mathrm{CDCl}_{3}\right): 3 E: \delta 143.55,135.29,128.43,125.92,125.53,118.07,31.67$, 23.23, 14.52, 14.37, 13.56. 3Z: $\delta 143.43,134.42,128.48,125.97,125.64,120.79$, 25.42, 22.34, 19.92, 14.59, 13.47. MS, m/z (relative abundance): $3 E: 172\left(\mathrm{M}^{+}, 19\right)$, 157 (100), 143 (72), 129 (80), 115 (44), 91 (50). 3Z: $172\left(\mathrm{M}^{+}, 32\right), 157$ (100), 143 (90), 129 (95), 115 (53), 91 (62), 79 (34).

The phosphonium salt, which is the precursor to the ylide, was prepared in $90 \%$ yield by mixing ethyliodide and equimolar amount of triphenylphosphine in a round bottomed flask for $12 \mathrm{~h}$ at ambient temperature. The phosphonium salt was collected as a white solid and washed with hot toluene. ${ }^{1} \mathrm{H}$ NMR $\left(500 \mathrm{MHz}, \mathrm{CDCl}_{3}\right): \delta 7.77(\mathrm{~m}$, 9H), $7.67(\mathrm{~m}, 6 \mathrm{H}), 3.70(\mathrm{~m}, 2 \mathrm{H}), 1.35\left(\mathrm{dt}, J_{l}=7.5 \mathrm{~Hz}, J_{2}=20.0 \mathrm{~Hz}, 3 \mathrm{H}\right)$.

\section{1-[2-(1-methyl-1-propenyl)cyclopropyl]benzene-PTAD ene $\operatorname{adduct} \quad(3 \mathrm{e})$.}

Compound 3e has two stereogonic centers and thus, is isolated as two pairs of enantiomers. In the ${ }^{1} \mathrm{H}$ NMR spectrum some of the peaks of the diastereomers separate to some extent (vide infra, spectra section).

${ }^{1} \mathrm{H}$ NMR (500 MHz, $\left.\mathrm{CDCl}_{3}\right): \delta 7.86(\mathrm{br}, \mathrm{N}-\mathrm{H}), 7.22(\mathrm{~m}, 10 \mathrm{H}), 5.04$ (s, 1H), 4.97 (s, 1H), $4.93(\mathrm{~m}, 1 \mathrm{H}), 1.95(\mathrm{~m}, 1 \mathrm{H}), 1.63(\mathrm{~m}, 1 \mathrm{H}), 1.44(\mathrm{~d}, J=6.6 \mathrm{~Hz}, 3 \mathrm{H}), 1.23(\mathrm{~m}, 1 \mathrm{H})$, $1.17(\mathrm{~m}, 1 \mathrm{H})$. 


\section{1-[2-(1-methyl-1-propenyl)cyclopropyl]benzene -PTAD trapping adduct (3t).}

Compound $3 \mathbf{t}$ was isolated as two pairs of enantiomers. In the ${ }^{1} \mathrm{H}$ NMR spectrum of these enantiomeric pairs, in $\mathrm{CD}_{3} \mathrm{OD}$, there is only a little separation of the peaks that correspond to the diastereomers; though, when the ${ }^{1} \mathrm{H}$ NMR spectrum is recorded in $\mathrm{CDCl}_{3}$, satisfactory separation for most of the peaks was observed (vide infra, spectra section).

${ }^{1} \mathrm{H}$ NMR $\left(500 \mathrm{MHz}, \mathrm{CD}_{3} \mathrm{OD}\right): \delta 7.50(\mathrm{~m}, 10 \mathrm{H}$ of $\mathbf{3 t}$ and $10 \mathrm{H}$ of $\mathbf{3 e}), 5.60(\mathrm{~m}, 1 \mathrm{H})$, $4.73(\mathrm{~m}, 1 \mathrm{H}), 4.33(\mathrm{~m}, 1 \mathrm{H}), 2.66(\mathrm{~m}, 1 \mathrm{H}), 2.55(\mathrm{~m}, 1 \mathrm{H}), 1.61(\mathrm{~s}, 3 \mathrm{H}), 1.47(\mathrm{~m}, 3 \mathrm{H})$

${ }^{1} \mathrm{H}$ NMR $\left(500 \mathrm{MHz}, \mathrm{CDCl}_{3}\right): \delta 7.35(\mathrm{~m}, 20 \mathrm{H}$ of $\mathbf{3 t}$ [both pairs of enantiomers] and $10 \mathrm{H}$ of $3 \mathbf{e}), 5.59\left(\mathrm{dd}, J_{1}=7.0, J_{2}=7.0 \mathrm{~Hz}, 1 \mathrm{H}\right.$ of the one pair of enantiomers), 5.46 $\left(\mathrm{dd}, J_{1}=7.3, J_{2}=7.3 \mathrm{~Hz}, 1 \mathrm{H}\right.$ of the other pair of enantiomers), $4.63(\mathrm{q}, J=6,7 \mathrm{~Hz}, 1 \mathrm{H}$ of the one pair of enantiomers), $4.59(\mathrm{q}, J=6.6 \mathrm{~Hz}, 1 \mathrm{H}$ of the other pair of enantiomers), 4.24 (m, 1H of RR, SS pair and 1H of RS, SR pair), 2.58 (m, 2H from the one pair of enantiomers and $1 \mathrm{H}$ from the other pair), $2.40(\mathrm{~m}, 1 \mathrm{H}$ from the other pair of enantiomers), 1.60 (s, 3H of the one pair of enantiomers), 1.54 (s, 3H of the other pair of enantiomers), $1.35(\mathrm{~d}, J=6.7 \mathrm{~Hz}, 3 \mathrm{H}$ of the one pair of enantiomers), $1.29(\mathrm{~d}, J=6.7 \mathrm{~Hz}, 3 \mathrm{H}$ of the other pair of enantiomers). 
Synthesis of compounds 9 and 10. Substrates 9 and 10 were prepared according to the following procedure:

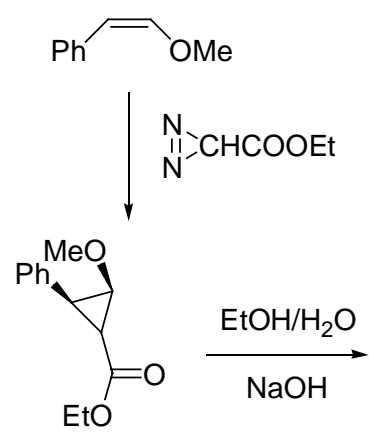

15

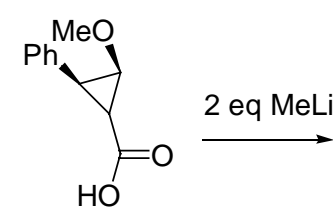

16

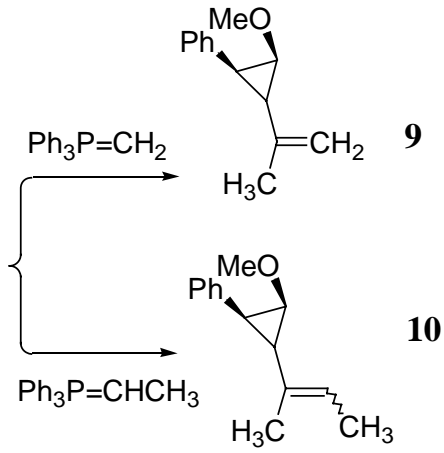

$\mathrm{E}, \mathrm{Z}=70 \%, 30 \%$

Ethyl trans,trans-2-methoxy-3-phenylcyclopropanecarboxylate (15), was prepared according to known experimental procedures (ref 17).

trans,trans-2-methoxy-3-phenylcyclopropanecarboxylic acid (16). A solution of carboxylic ester 15 (2.8 g. $12.8 \mathrm{mmol})$ and $\mathrm{NaOH}(1.0 \mathrm{~g})$ in $95 \%$ ethanol $(50 \mathrm{~mL})$ was heated at reflux for $2 \mathrm{~h}$, cooled and evaporated. The solid was dissolved in water and extracted twice with ether. The aqueous phase was acidified with concentrated $\mathrm{HCl}$ up to $\mathrm{pH}=4$ and then extracted with ether, dried over $\mathrm{MgSO}_{4}$ and concentrated at reduced pressure to afford $16(2.1 \mathrm{~g}, 11.0 \mathrm{mmol}, 86 \%)$ as a solid. ${ }^{1} \mathrm{H}$ NMR (500 $\left.\mathrm{MHz}, \mathrm{CDCl}_{3}\right): \delta 2.22\left(\mathrm{dd}, J_{l}=6.0 \mathrm{~Hz}, J_{2}=2.4 \mathrm{~Hz}, 1 \mathrm{H}\right), 2.81(\mathrm{t}, J=6.0 \mathrm{~Hz}, 1 \mathrm{H}), 3.38$ (s, 3H), $3.92\left(\mathrm{dd}, J_{1}=7.2 \mathrm{~Hz}, J_{2}=2.4 \mathrm{~Hz}, 1 \mathrm{H}\right), 7.26-7.36(\mathrm{~m}, 5 \mathrm{H}) .{ }^{13} \mathrm{C} \mathrm{NMR}(125$ $\left.\mathrm{MHz}, \mathrm{CDCl}_{3}\right): \delta 27.88,33.31,58.82,66.62,126.91,128.23,128.42,134.16,178.10$.

(trans, trans-2-Methoxy-3-phenylcyclopropyl)ethanone (17). ${ }^{\mathrm{i}} \mathrm{MeLi}(16.0 \mathrm{~mL}, 1.5$ $\mathrm{M}$ in ether, $24.0 \mathrm{mmol}$ ) was slowly added, under a nitrogen atmosphere, to a cooled 
solution $\left(-78{ }^{\circ} \mathrm{C}\right)$ of carboxylic acid $16(2.1 \mathrm{~g}, 11.0 \mathrm{mmol})$ in anhydrous ether. The reaction mixture was stirred at $-78{ }^{\circ} \mathrm{C}$ for $15 \mathrm{~min}$ and then warmed to $0{ }^{\circ} \mathrm{C}$, stirred for $1 \mathrm{~h}$, and carefully treated with water. The etheral phase was separated, dried over $\mathrm{MgSO}_{4}$ and evaporated to provide ketone 17 as an oil $(1.6 \mathrm{~g}, 8.4 \mathrm{mmol}, 77 \%) .{ }^{1} \mathrm{H}$ $\operatorname{NMR}\left(500 \mathrm{MHz}, \mathrm{CDCl}_{3}\right): \delta 2.38(\mathrm{~s}, 3 \mathrm{H}), 2.56\left(\mathrm{dd}, J_{l}=5.8 \mathrm{~Hz}, J_{2}=2.3 \mathrm{~Hz}, 1 \mathrm{H}\right), 2.83$ $(\mathrm{t}, J=6.4 \mathrm{~Hz}, 1 \mathrm{H}), 3.32(\mathrm{~s}, 3 \mathrm{H}), 3.85\left(\mathrm{dd}, J_{1}=6.9 \mathrm{~Hz}, J_{2}=2.3 \mathrm{~Hz}, 1 \mathrm{H}\right), 7.25-7.35(\mathrm{~m}$, 5H). ${ }^{13} \mathrm{C} \mathrm{NMR}\left(125 \mathrm{MHz}, \mathrm{CDCl}_{3}\right): \delta 31.05,34.99,37.05,58.71,68.87,126.67$, $128.18,128.21,135.10,205.49 . \mathrm{MS}, \mathrm{m} / \mathrm{z}$ (relative abundance $)=147\left(\mathrm{M}^{+}, 93\right)$

1-(2-isopropenyl-3-methoxycyclopropyl)benzene (9). $n$-BuLi (7.9 mL, $11 \mathrm{mmol}$, 1.4 $\mathrm{M}$ in hexanes) was added to a cooled mixture $\left(0{ }^{\circ} \mathrm{C}\right)$ of $\mathrm{CH}_{3}{ }^{+} \mathrm{PPh}_{3} \mathrm{I}^{-}$in dry THF under a $\mathrm{N}_{2}$ atmosphere. The solution turned red due to the formation of the corresponding ylide. After the mixture was stirred for $1 \mathrm{~h}$ at room temperature, a solution of ketone 17 (1.6 g, $8.4 \mathrm{mmol})$ in $10 \mathrm{~mL}$ of dry THF was added dropwise. The resulting mixture was stirred at room temperature for $20 \mathrm{~h}$ and then poured into $100 \mathrm{~mL}$ of hexanes. Triphenylphosphine oxide $\left(\mathrm{Ph}_{3} \mathrm{PO}\right)$ precipitated. The filtrated solution was concentrated, and the residue was chromatographed $\left(\mathrm{SiO}_{2}\right.$, hexane with a few drops of triethylamine) to give $0.316 \mathrm{~g}$ of alkene 9 (1.7 mmol, $20 \%) .{ }^{1} \mathrm{H}$ NMR $\left(500 \mathrm{MHz}, \mathrm{CDCl}_{3}\right): \delta 7.32(\mathrm{~m}, 4 \mathrm{H}), 7.24(\mathrm{~m}, 1 \mathrm{H}), 4.80(\mathrm{~s}, 1 \mathrm{H}), 4.76(\mathrm{~s}, 1 \mathrm{H}), 3.49(\mathrm{~m}$ 1H), $3.25(\mathrm{~s}, 3 \mathrm{H}), 2.23(\mathrm{t}, J=6.7 \mathrm{~Hz}, 1 \mathrm{H}), 2.03(\mathrm{~m}, 1 \mathrm{H}), 1.84(\mathrm{~s}, 3 \mathrm{H}) .{ }^{13} \mathrm{C}$ NMR $(125$ $\left.\mathrm{MHz}, \mathrm{CDCl}_{3}\right): \delta 143.47,137.32,128.03,127.98,125.78,109.11,66.05,58.19,32.97$ 30.61, 21.97. MS, m/z (relative abundance): $188\left(\mathrm{M}^{+}, 23\right), 187$ (26), 173 (89), 156 (100), 141 (87), 128 (79), 115 (99), 105 (35), 91 (79), 77 (56). The precursor to the ylide, the phosphonium salt, was prepared similarly with the corresponding precursor of substrate 9 (vide supra). 


\section{1-(2-isopropenyl-3-methoxycyclopropyl)benzene-PTAD trapping adduct (9t).}

${ }^{1} \mathrm{H}$ NMR $\left(500 \mathrm{MHz}, \mathrm{CDCl}_{3}\right): \delta 7.30(\mathrm{~m}, 10 \mathrm{H}), 5.91(\mathrm{~d}, J=9.5 \mathrm{~Hz}, 1 \mathrm{H}), 4.53(\mathrm{~d}, J=$ $6.0 \mathrm{~Hz}, 1 \mathrm{H}), 4.29(\mathrm{~d}, J=14.0 \mathrm{~Hz}, 1 \mathrm{H}), 4.05(\mathrm{~d}, J=14.0 \mathrm{~Hz}, 1 \mathrm{H}), 3.87\left(\mathrm{dd}, J_{l}=9.5\right.$ $\left.\mathrm{Hz}, J_{2}=6.0 \mathrm{~Hz}, 1 \mathrm{H}\right), 3.34(\mathrm{~s}, 3 \mathrm{H}), 1.72(\mathrm{~s}, 3 \mathrm{H})$.

1-[2-methoxy-3-(1-methyl-1-propenyl)cyclopropyl]benzene (10). Alkene 10 was prepared as a mixture of $E$ and $Z$ isomers (70/30 ratio respectively) from ketone 17 according to the above-mentioned process for alkene 9. The reagents and quantities used are the following: ketone 17: $0.67 \mathrm{~g}(3.5 \mathrm{mmol})$; phosphonium salt $\left(\mathrm{CH}_{3} \mathrm{CH}_{2}{ }^{+} \mathrm{PPh}_{3} \mathrm{I}^{-}\right): 2.3 \mathrm{~g}(5.5 \mathrm{mmol})$; solution of $n-\mathrm{BuLi}$ (1.2 M in hexane): $3.4 \mathrm{ml}$ (4.0 mmol). $0.28 \mathrm{~g}$ of $\mathbf{5}$ was collected (yield $40 \%$ ), after the purification of the crude

mixture of the olefin by column chromatography $\left(\mathrm{SiO}_{2}\right.$, hexane with a few drops of triethylamine),. 10E: ${ }^{1} \mathrm{H}$ NMR (500 MHz, $\left.\mathrm{CDCl}_{3}\right): \delta 7.32(\mathrm{~m}, 4 \mathrm{H}), 7.20(\mathrm{~m}, 1 \mathrm{H}), 5.34$ $(\mathrm{q}, J=6.7 \mathrm{~Hz}, 1 \mathrm{H}), 3.43(\mathrm{~m}, 1 \mathrm{H}), 3.22(\mathrm{~s}, 3 \mathrm{H}), 2.14(\mathrm{t}, J=6.8 \mathrm{~Hz}, 1 \mathrm{H}), 2.01(\mathrm{~m}, 1 \mathrm{H})$, $1.69(\mathrm{~s}, 3 \mathrm{H}), 1.63(\mathrm{~d}, J=7.4 \mathrm{~Hz}, 3 \mathrm{H}) .{ }^{13} \mathrm{C} \mathrm{NMR}\left(125 \mathrm{MHz}, \mathrm{CDCl}_{3}\right): \delta 137.78,133.18$, $127.98,127.92,125.58,118.62,65.51,58.14,34.44,29.64,15.36,13.29 . \mathrm{MS}, \mathrm{m} / \mathrm{z}$ (relative abundance): $202(\mathrm{M}+, 23), 187$ (100), 170 (32), 155 (65), 141 (22), 129 (37), 115 (57), 105 (18), 91 (65), 77 (33). 10Z: ${ }^{1} \mathrm{H}$ NMR (500 MHz, $\mathrm{CDCl}_{3}$ ): $\delta 7.32$ (m, 4H), $7.20(\mathrm{~m}, 1 \mathrm{H}), 5.40(\mathrm{q}, J=6.7 \mathrm{~Hz}, 1 \mathrm{H}), 3.58(\mathrm{~m}, 1 \mathrm{H}), 3.22(\mathrm{~s}, 3 \mathrm{H}), 2.25(\mathrm{~m}, 1 \mathrm{H})$, $2.18(\mathrm{t}, J=6.8 \mathrm{~Hz}, 1 \mathrm{H}), 1.71(\mathrm{~d}, J=6.8 \mathrm{~Hz}, 3 \mathrm{H}), 1.62(\mathrm{~s}, 3 \mathrm{H}) .{ }^{13} \mathrm{C}$ NMR $(125 \mathrm{MHz}$, $\left.\mathrm{CDCl}_{3}\right): \delta 137.78,133.18,127.98,127.89,125.67,121.50,65.13,58.14,29.86,28.92$ 20.86, 13.60. MS, m/z (relative abundance): 202 (M+, 26), 187 (100), 170 (29), 155 (66), 143 (22), 129 (36), $115(54), 91$ (65), 77 (40).

The precursor to the ylide, the phosphonium salt, was prepared as mentioned above. 


\section{1-[2-methoxy-3-(1-methyl-1-propenyl)cyclopropyl]benzene-PTAD}

adduct (10t).

Compound 10t was isolated as two pairs of enantiomers (RR, SS and RS, SR). In the

${ }^{1} \mathrm{H}$ NMR spectrum of these diastereomeric pairs, in $\mathrm{CD}_{3} \mathrm{OD}$, satisfactory separation for most of the peaks that correspond to the diastereomers was observed (vide infra, spectra section).

${ }^{1} \mathrm{H}$ NMR (500 MHz, $\left.\mathrm{CD}_{3} \mathrm{OD}\right): \delta 7.40$ (m, 20H [both pairs of enantiomers: RR, SS pair $10 \mathrm{H}$ and RS, SR pair $10 \mathrm{H}$ ], $5.97(\mathrm{~d}, J=8.5 \mathrm{~Hz}, 1 \mathrm{H}$ of the one pair of enantiomers), $5.92(\mathrm{~d}, J=9.0 \mathrm{~Hz}, 1 \mathrm{H}$ of the other pair of enantiomers $), 4.74(\mathrm{~m}, 1 \mathrm{H}$ of each pair of enantiomers), 4.57 (d, $J=6.0 \mathrm{~Hz}, 1 \mathrm{H}$ of the one pair of enantiomers), 4.55 (d, $J=6.0$ $\mathrm{Hz}, 1 \mathrm{H}$ of the other pair of enantiomers), 3.88 (m, 1H of each pair of enantiomers), $3.31(\mathrm{~s}, 3 \mathrm{H}$ of the one pair of enantiomers), $3.28(\mathrm{~s}, 3 \mathrm{H}$ of the other pair of enantiomers), 1.70 (s, $3 \mathrm{H}$ of the one pair of enantiomers), 1.68 (s, 3H of the other pair of enantiomers $), 1.49(\mathrm{~m}, 3 \mathrm{H}$ of the one pair of enantiomers and $3 \mathrm{H}$ of the other pair of enantiomers).

\section{Additional References}

i. $\quad$ Paquette, L. A.; Ham W. H. J. Am. Chem. Soc. 1987, 109, 3025-3036. 
B) ${ }^{1}$ H NMR spectra section

${ }^{1} \mathrm{H}$ NMR spectrum (500 MHz, $\mathrm{CDCl}_{3}$ ) of alkene 2
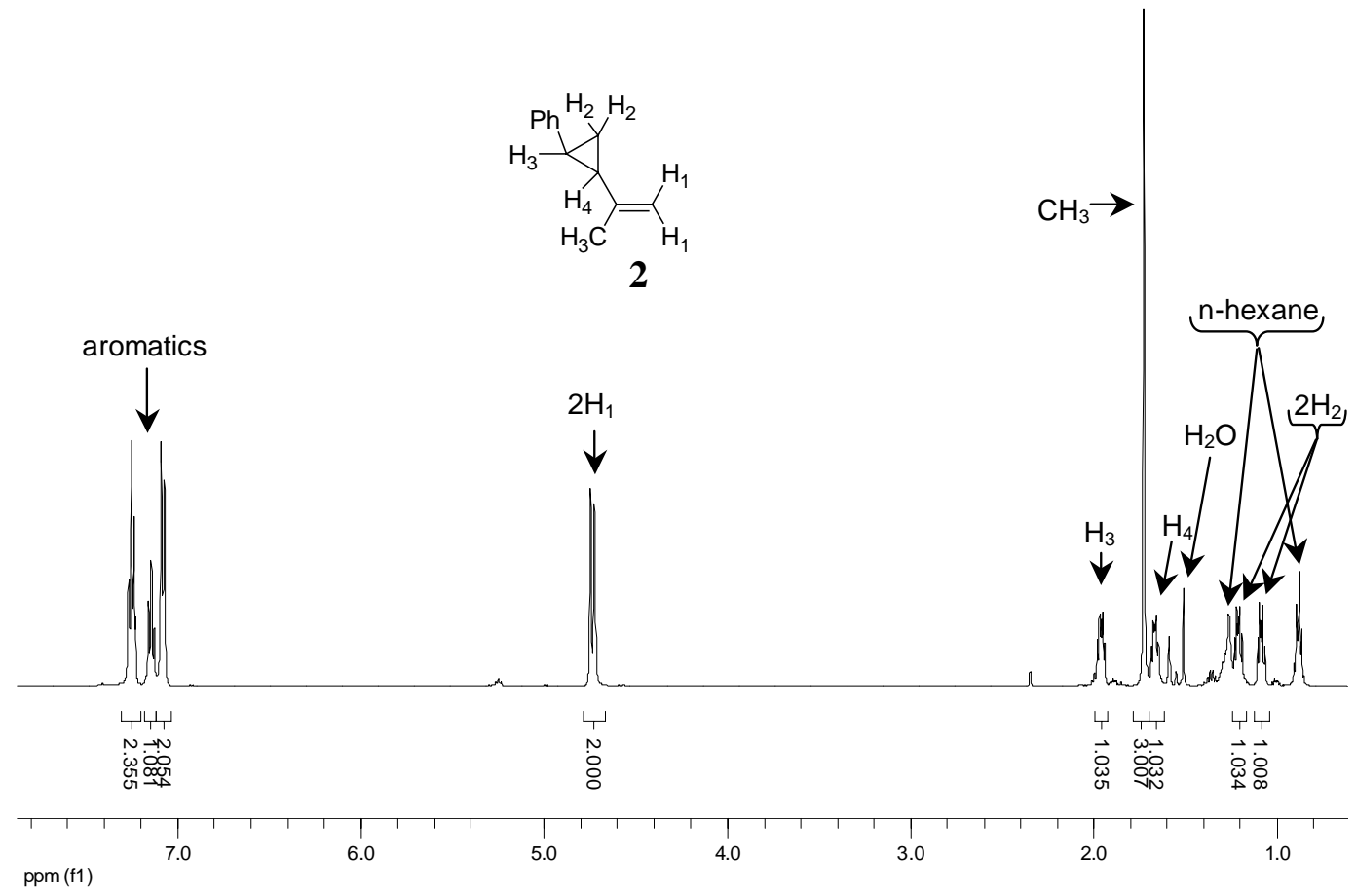

${ }^{1} \mathrm{H}$ NMR spectrum $\left(500 \mathrm{MHz}, \mathrm{CDCl}_{3}\right)$ from the reaction of 2 with PTAD in $\mathrm{CDCl}_{3}$.

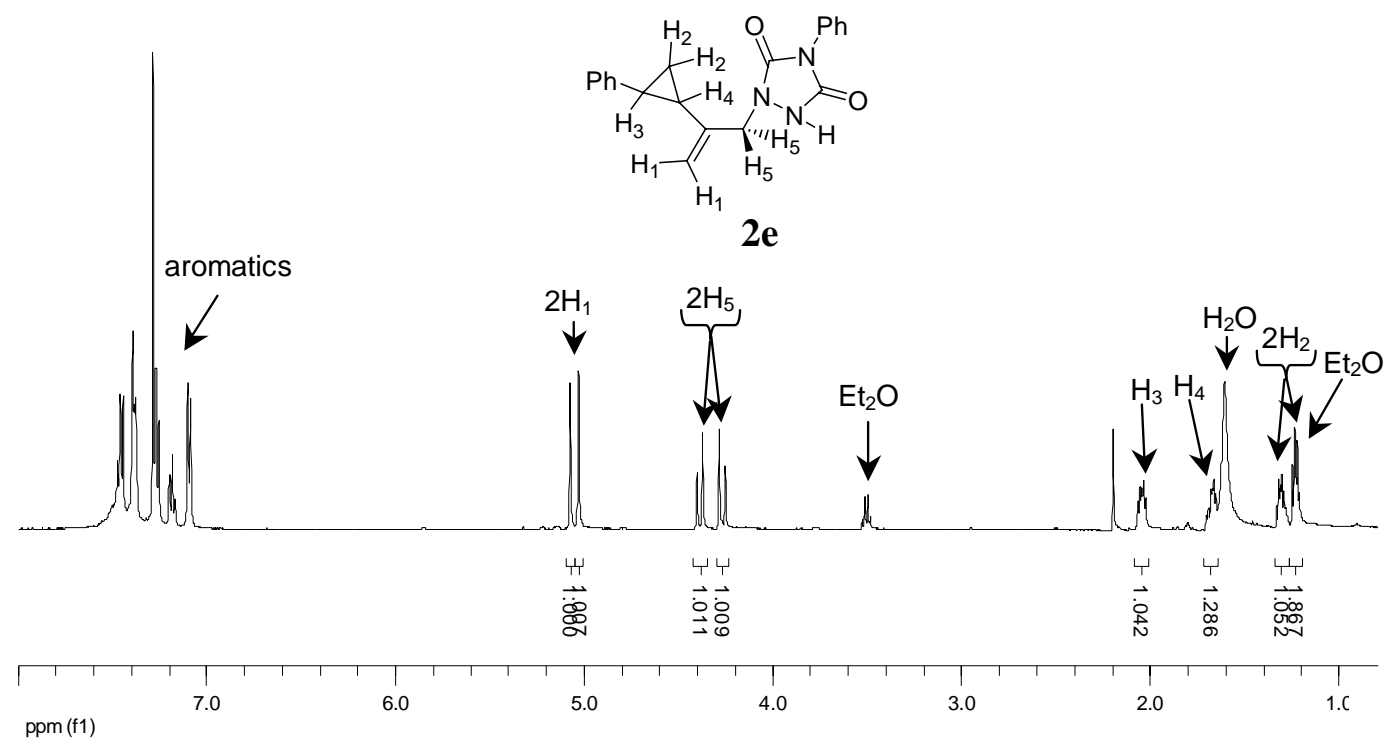


${ }^{1} \mathrm{H}$ NMR spectrum (500 $\mathrm{MHz}, \mathrm{CDCl}_{3}$ ) from the reaction of 2 with PTAD in $\mathrm{CD}_{3} \mathrm{OD}$.

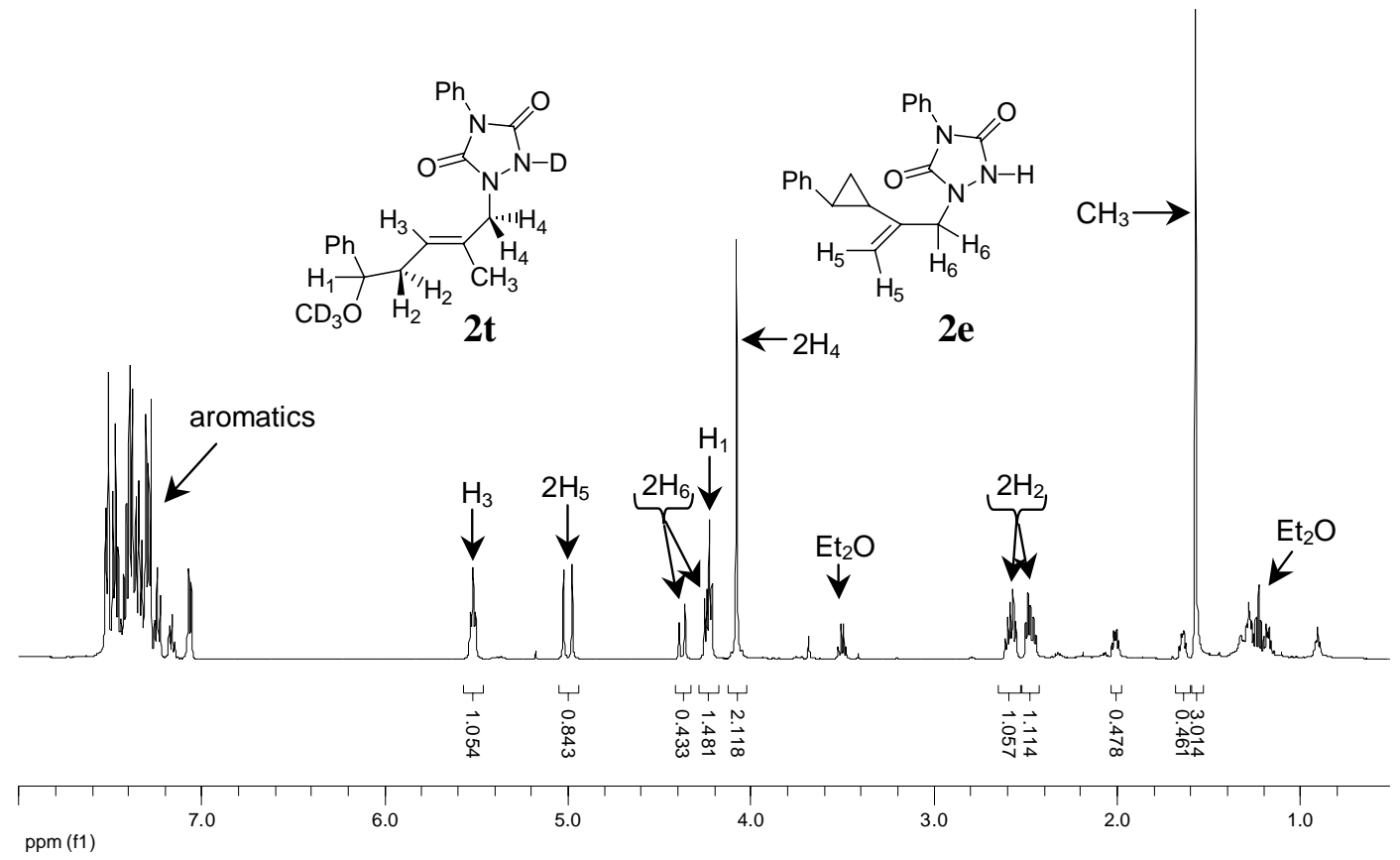

${ }^{1} \mathrm{H}$ NMR spectrum (500 MHz, $\left.\mathrm{CDCl}_{3}\right)$ of alkene 3 . 


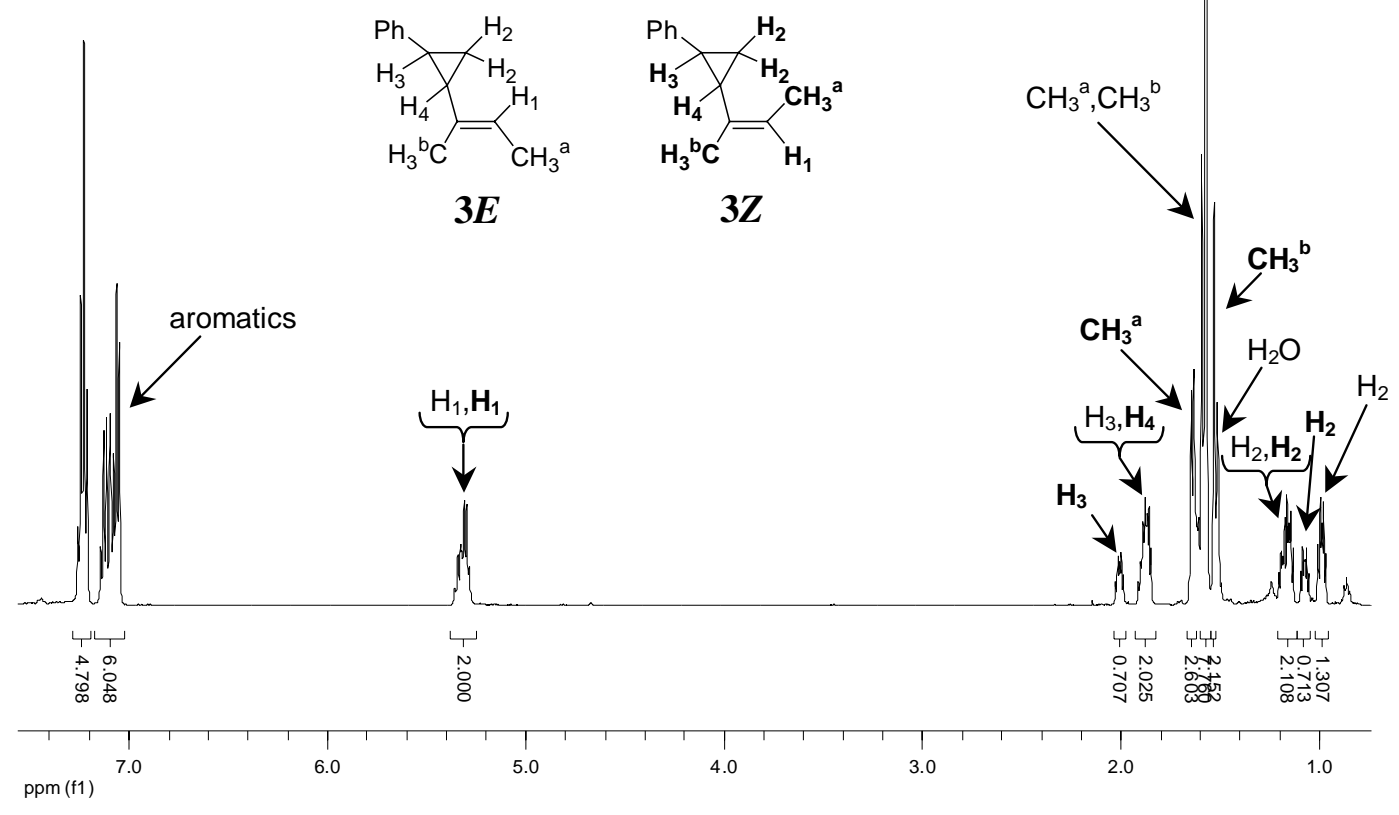

${ }^{1} \mathrm{H}$ NMR spectrum (500 $\mathrm{MHz}, \mathrm{CDCl}_{3}$ ) from the reaction of 3 with PTAD in $\mathrm{CDCl}_{3}$.
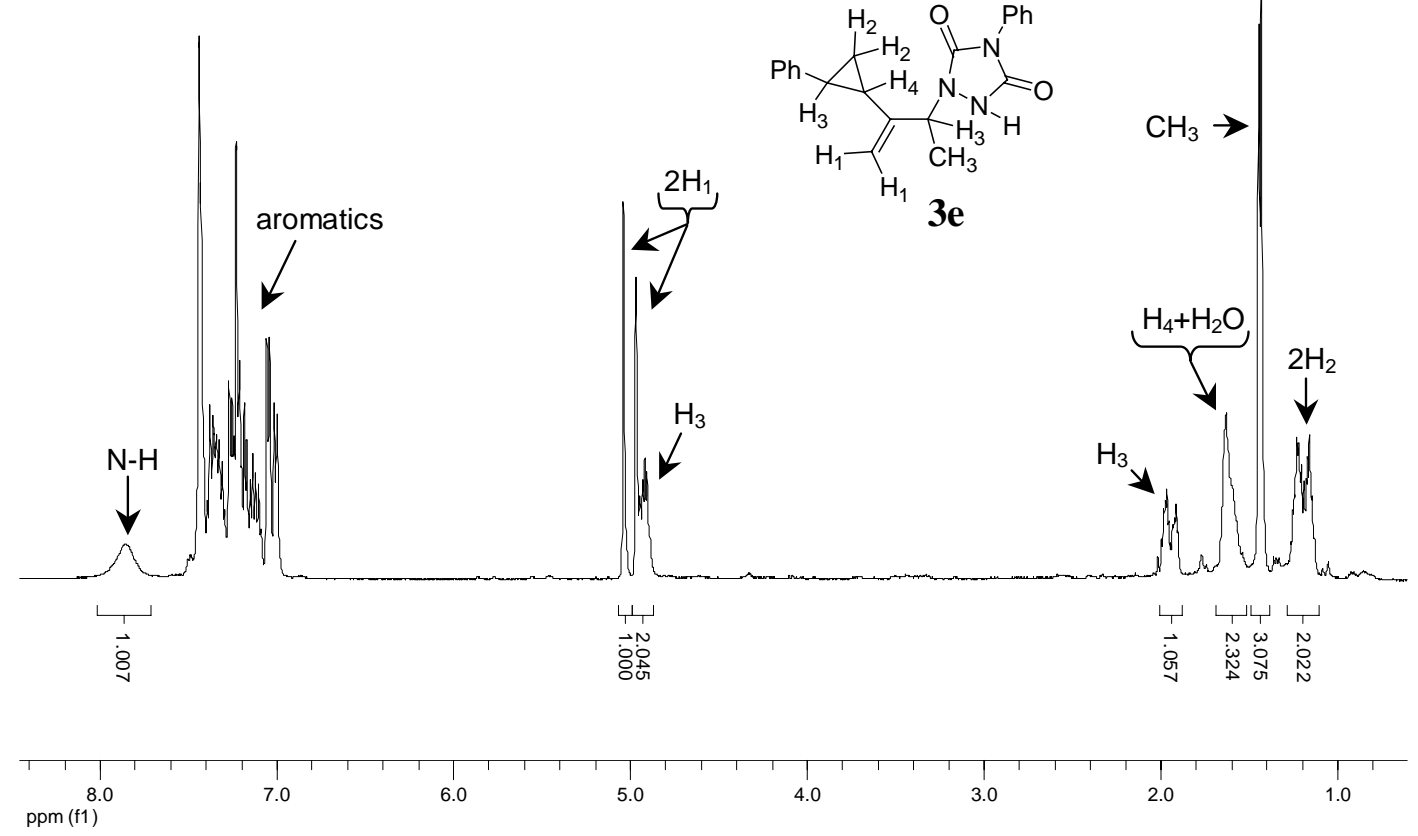
${ }^{1} \mathrm{H}$ NMR spectrum $\left(500 \mathrm{MHz}, \mathrm{CD}_{3} \mathrm{OD}\right)$ from the reaction of 3 with $\mathrm{PTAD}$ in $\mathrm{CD}_{3} \mathrm{OD}$.

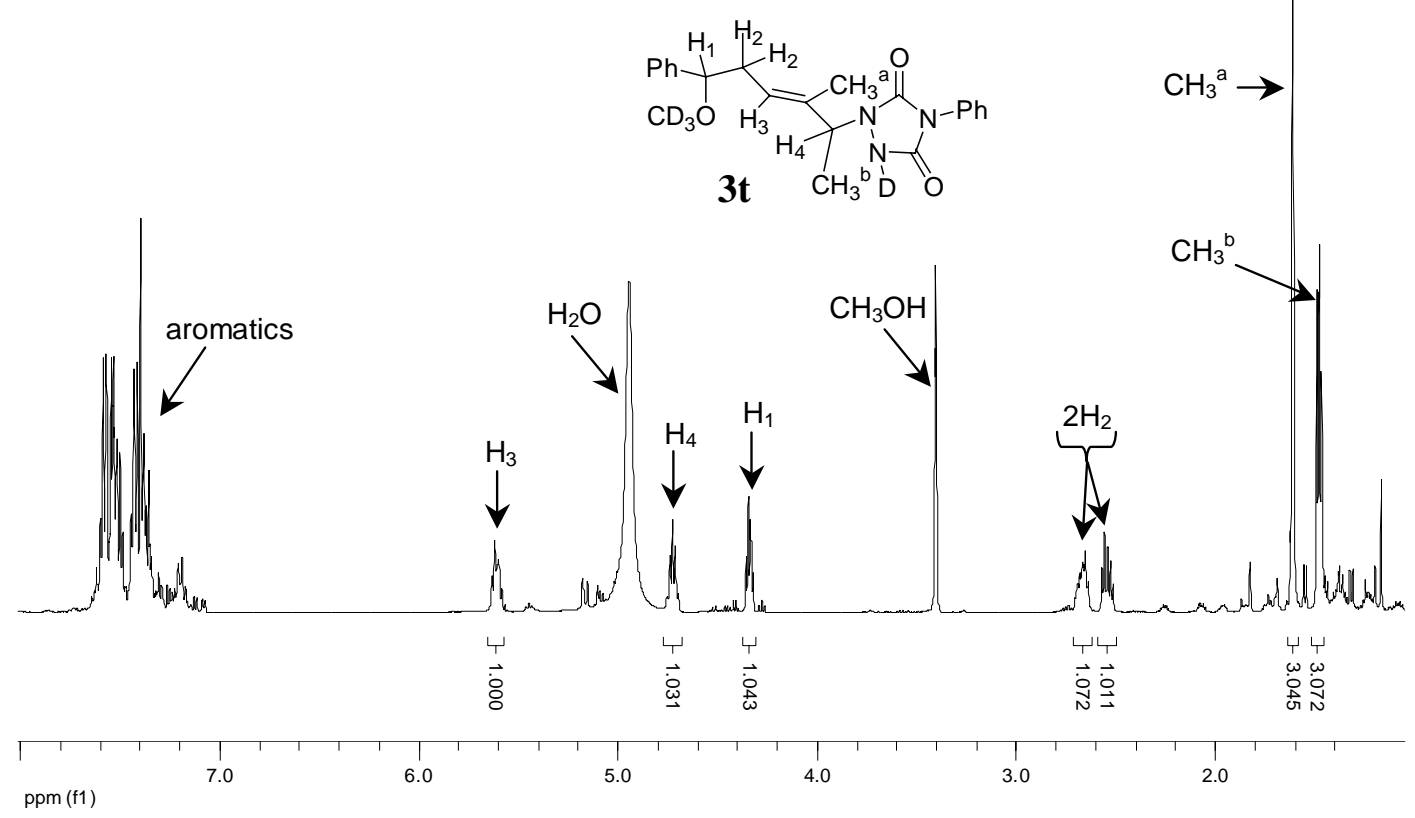

S13

${ }^{1} \mathrm{H}$ NMR spectrum $\left(500 \mathrm{MHz}, \mathrm{CDCl}_{3}\right.$ ) from the reaction of 3 with PTAD in $\mathrm{CD}_{3} \mathrm{OD}$ (aromatic region is omitted for clarity). 


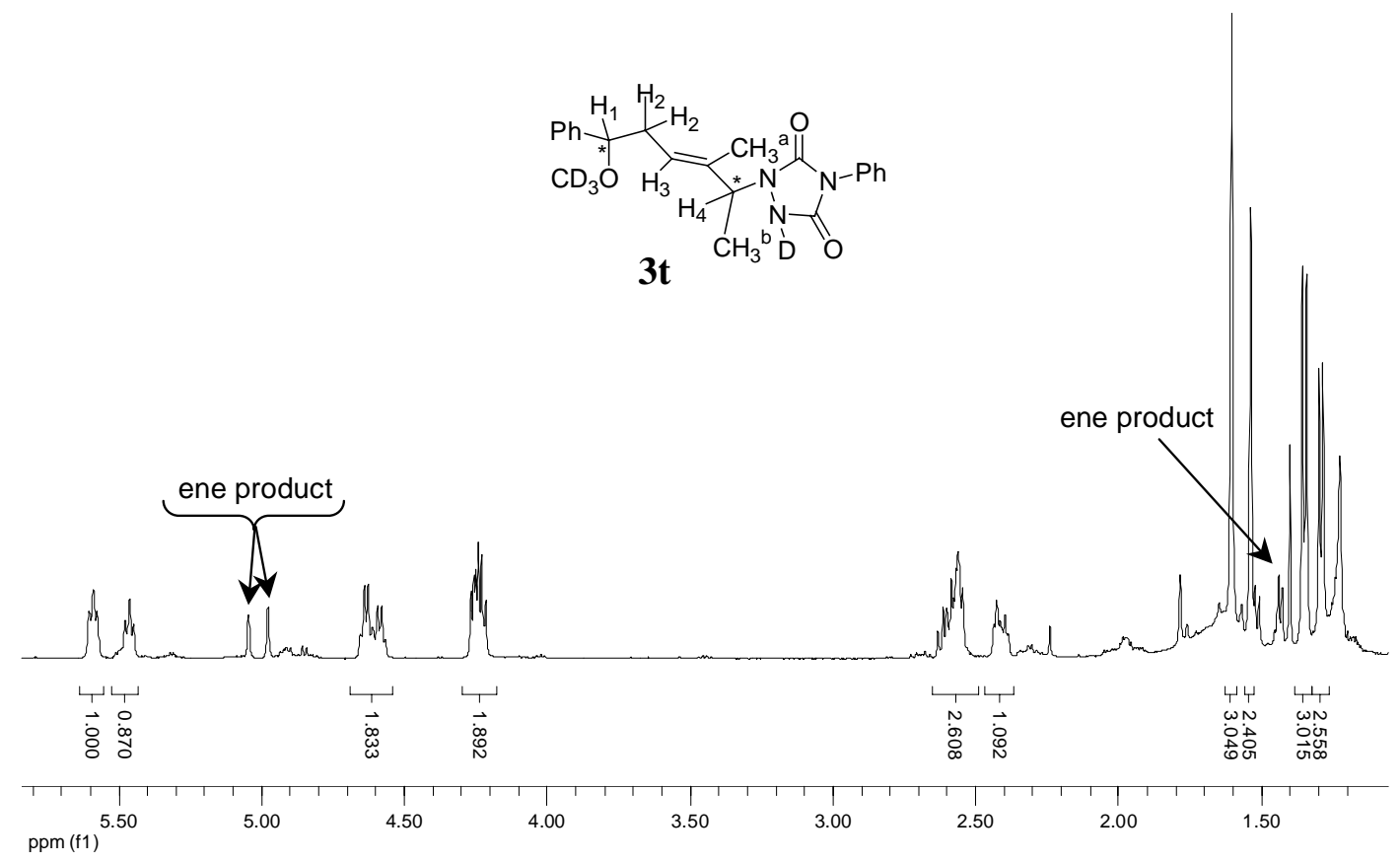

${ }^{1} \mathrm{H}$ NMR spectrum $\left(500 \mathrm{MHz}, \mathrm{CDCl}_{3}\right)$ of alkene 9.

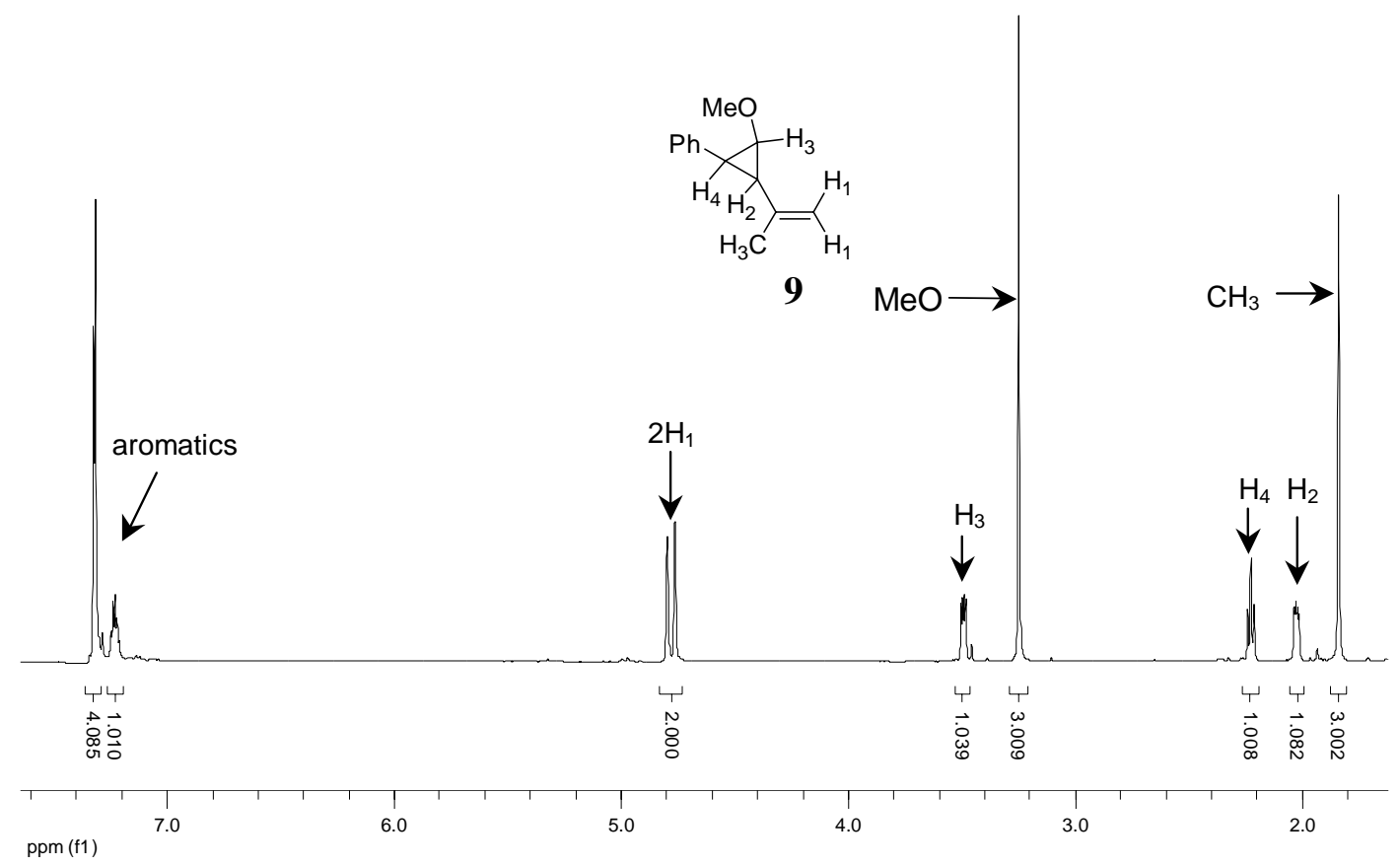

${ }^{1} \mathrm{H}$ NMR spectrum (500 $\mathrm{MHz}, \mathrm{CDCl}_{3}$ ) from the reaction of 9 with PTAD in $\mathrm{CD}_{3} \mathrm{OD}$. 


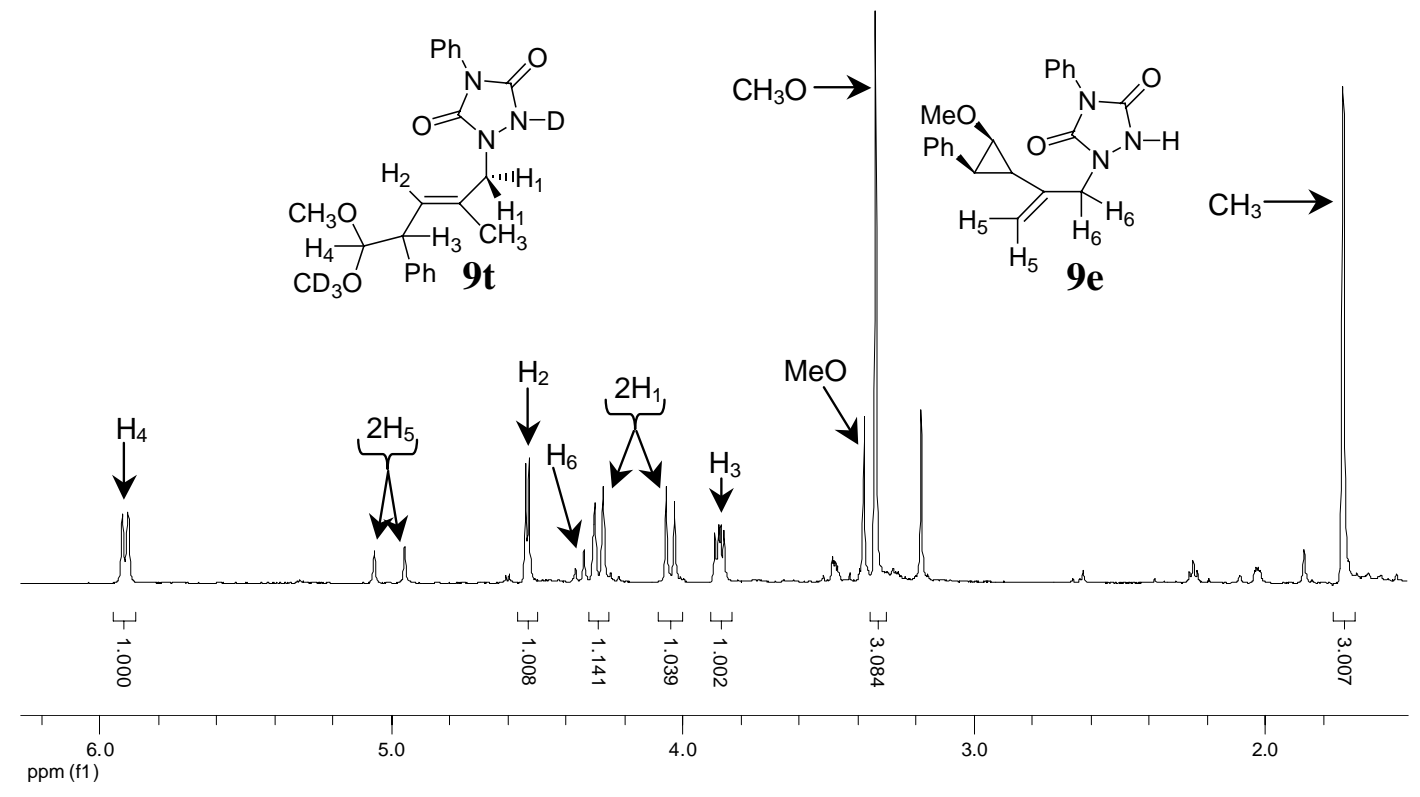

${ }^{1} \mathrm{H}$ NMR spectrum (500 MHz, $\mathrm{CDCl}_{3}$ ) of alkene 10 .

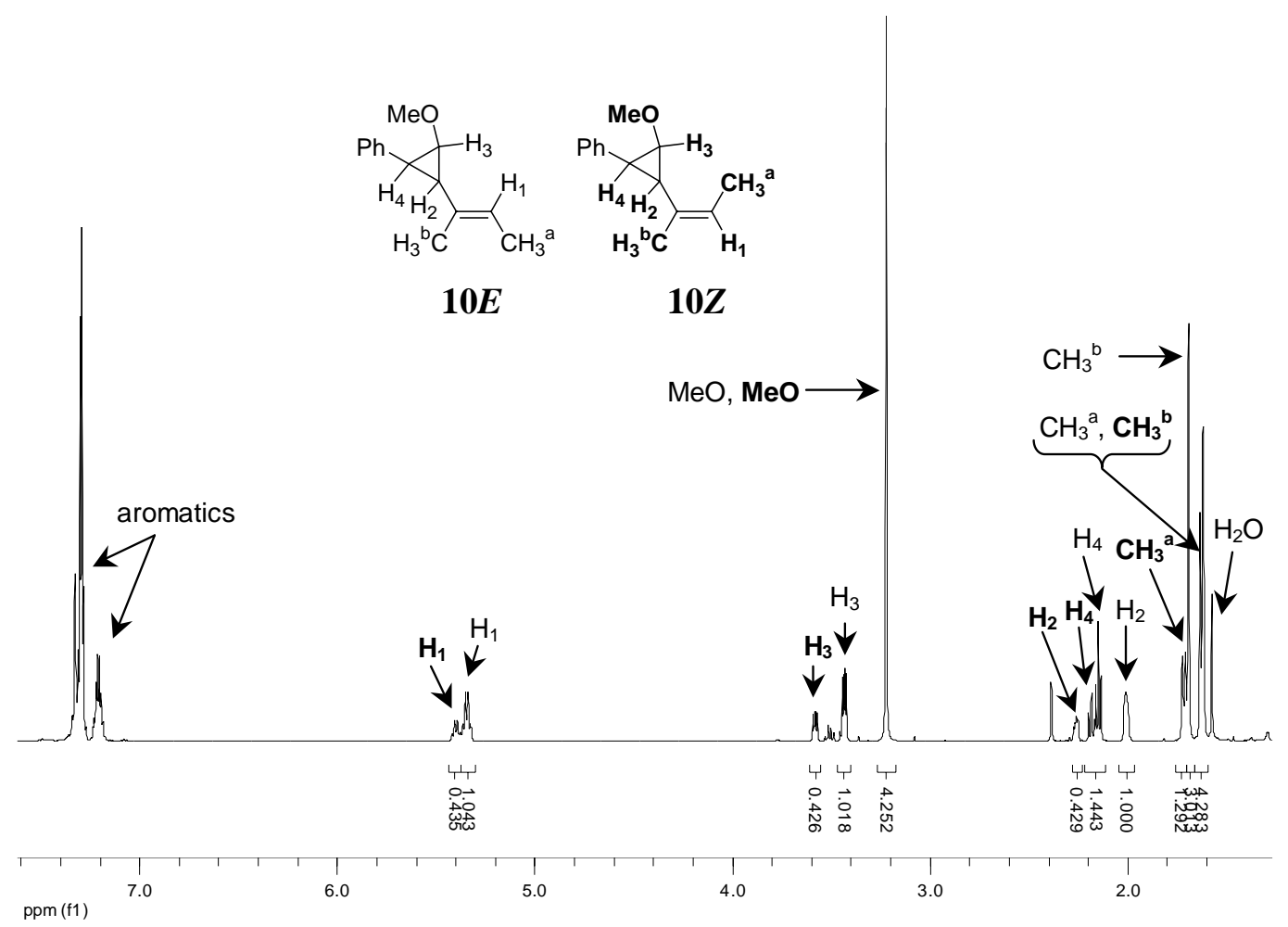


${ }^{1} \mathrm{H}$ NMR spectrum $\left(500 \mathrm{MHz}, \mathrm{CD}_{3} \mathrm{OD}\right)$ from the reaction of alkene 10 with PTAD in $\mathrm{CD}_{3} \mathrm{OD}$ (aromatic region is omitted for clarity).

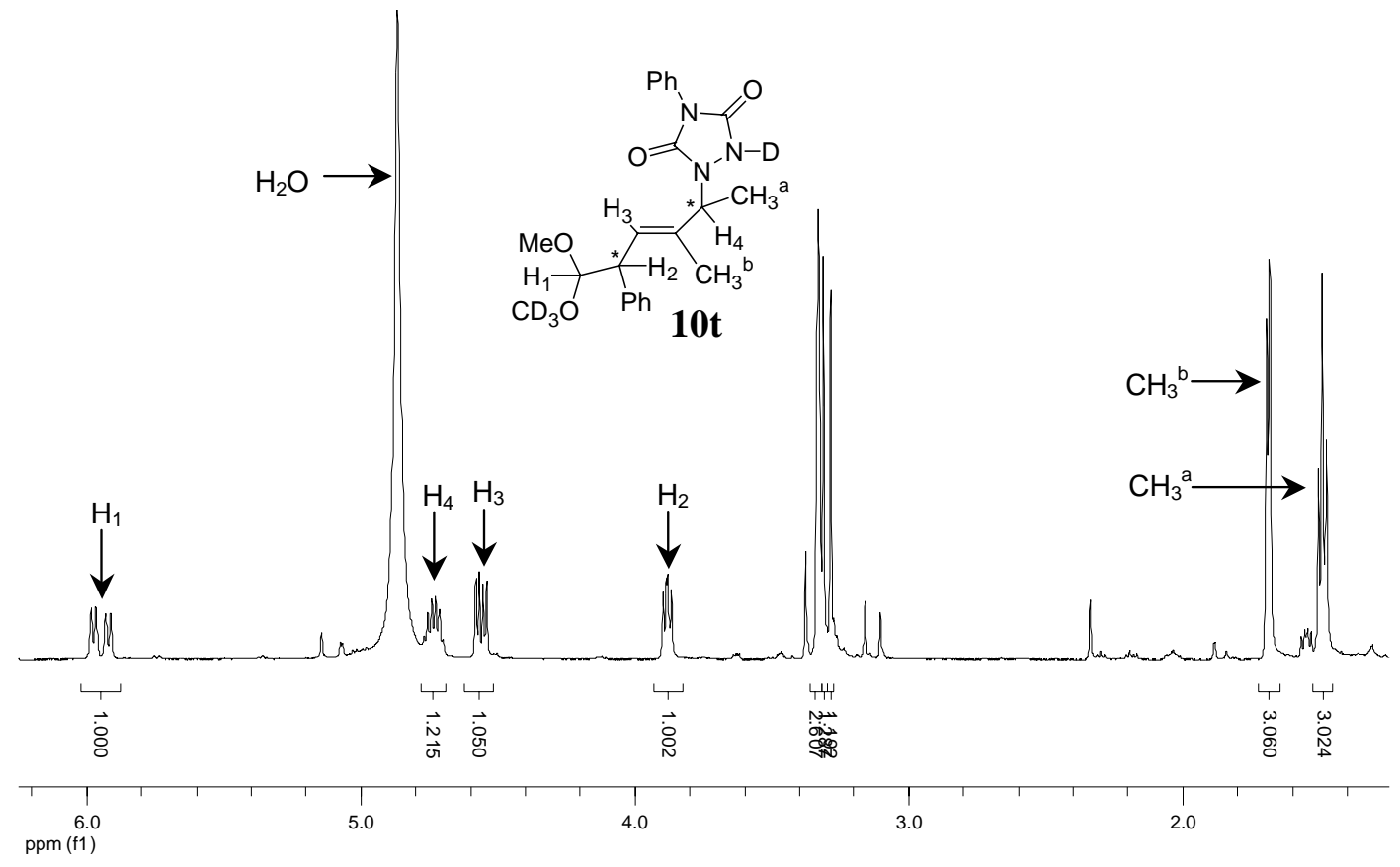


C) Nuclear Overhauser effect difference experiments (DNOE, 500 $\mathrm{MHz}, \mathrm{CDCl}_{3}$ ) for the determination of the stereochemistry of the newly formed double bonds in $2 \mathrm{t}$ and $9 \mathrm{t}$.
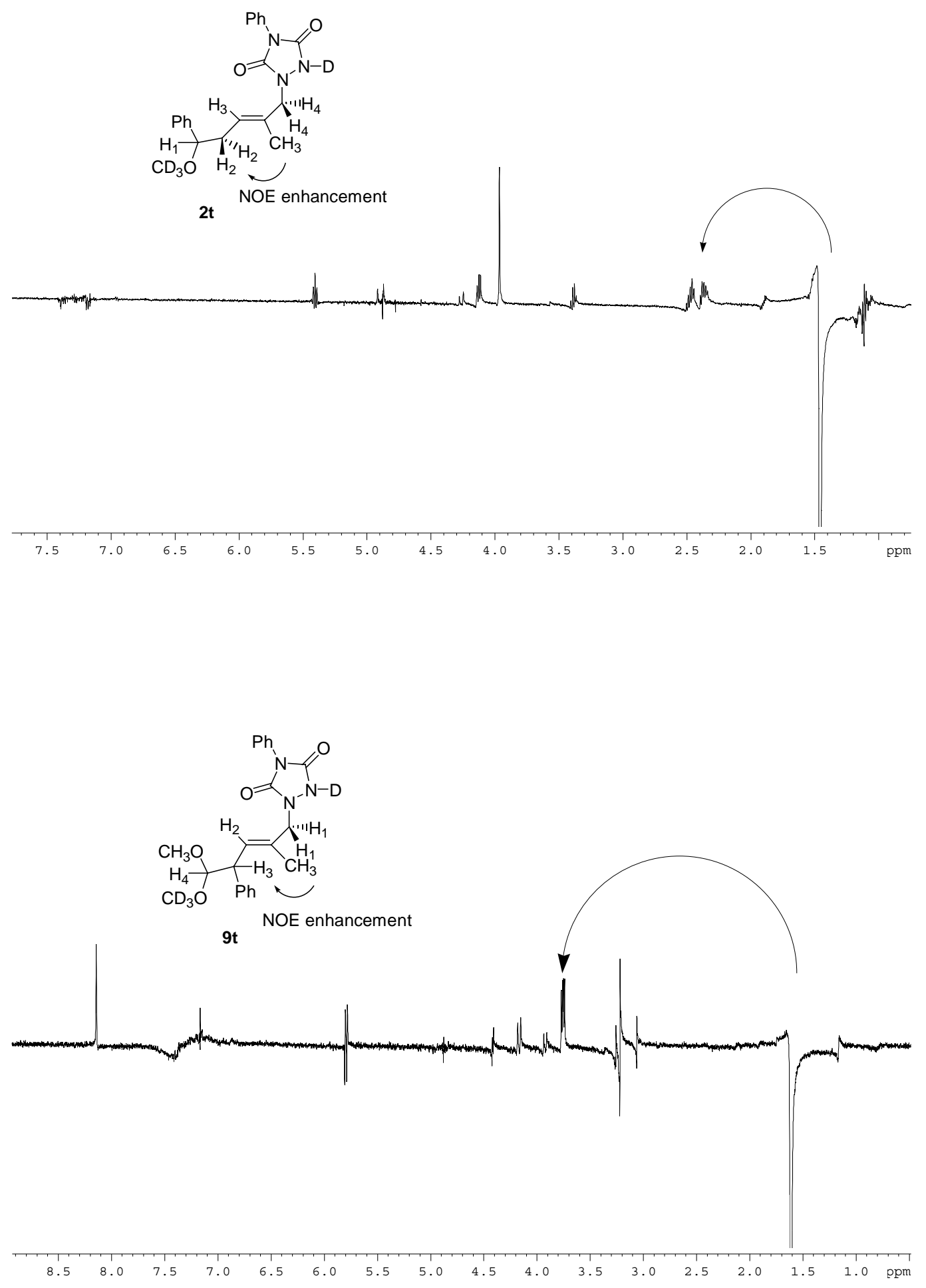